\title{
DNA ploidy may be a prognostic marker in stage I and II serous adenocarcinoma of the endometrium
}

\author{
Manohar Pradhan • Ben Davidson • Vera Maria Abeler • \\ Håvard Emil Danielsen • Claes Göran Tropé • \\ Gunnar Balle Kristensen • Björn Åke Risberg
}

Received: 27 April 2012 /Revised: 11 June 2012 / Accepted: 25 June 2012 / Published online: 24 July 2012

(C) The Author(s) 2012. This article is published with open access at Springerlink.com

\begin{abstract}
In patients with serous adenocarcinoma (SAC) of the endometrium, we evaluated the prognostic importance of clinicopathological parameters, DNA ploidy, and immunoexpression of $\mathrm{p} 53$, estrogen receptor (ER), progesterone receptor (PR), and Ki-67. In a series of 73 stage I and II SAC, DNA ploidy analysis was performed on hysterectomy specimens using DNA image cytometry. Immunohistochemical analysis of p53, ER, PR, and Ki-67 expression was additionally performed. In the review of the histological slides by three gynecologic pathologists, the presence of a
\end{abstract}

M. Pradhan · H. E. Danielsen • G. B. Kristensen • B. Å. Risberg Institute for Medical Informatics, Oslo University Hospital, Oslo, Norway

M. Pradhan · B. Davidson • V. M. Abeler

Department of Pathology, Oslo University Hospital,

Oslo, Norway

M. Pradhan • H. E. Danielsen

Center for Cancer Biomedicine, University of Oslo,

Oslo, Norway

B. Davidson · C. G. Tropé

The Medical Faculty, University of Oslo,

Oslo, Norway

H. E. Danielsen

Department of Informatics, University of Oslo,

Oslo, Norway

C. G. Tropé • G. B. Kristensen

Department of Gynecological Oncology, Oslo University Hospital, Oslo, Norway

B. Å. Risberg $(\bowtie)$

Department of Pathology, The Norwegian Radium Hospital,

Oslo University Hospital,

Montebello,

0310 Oslo, Norway

e-mail: BRB@ous-hf.no serous component was not agreed upon in 17 (23\%) cases. The remaining 56 cases, consisting of pure SAC or SAC mixed with endometrioid adenocarcinoma, were further analyzed. Tumor recurrence was observed in 14 patients, and 28 patients died during the follow-up period. Patients with diploid $(n=19)$, aneuploid $(n=29)$, and tetraploid $(n=8)$ tumor had 5 -year recurrence rates of 10,38 , and $53 \%$, respectively $(p=0.09)$. A DNA ploidy parameter, $5 c$ exceeding rate, was found to be a prognostic marker for recurrence $(p=0.03)$, progression-free survival $(p<0.01)$, and overall survival $(p=0.02)$. Immunoexpression of $\mathrm{p} 53$, ER, PR, and Ki-67 did not have prognostic value, and the same was true for FIGO stage, lymphovascular invasion, the extent of myometrial invasion, and lymphadenectomy. The histological diagnosis of SAC may be difficult in some cases. Established clinicopathological parameters do not seem to be strong prognosticators in stage I and II disease. A DNA ploidy parameter, $5 \mathrm{c}$ exceeding rate, may be a prognostic marker in this patient group and should be further validated in larger series.

Keywords Serous adenocarcinoma $\cdot$ Endometrial carcinoma $\cdot$ DNA ploidy $\cdot$ p53 $\cdot$ Estrogen receptor . Progesterone receptor

\section{Introduction}

Endometrial carcinoma (EC), the most common gynecological malignancy in the Western world, is considered to be a relatively less aggressive tumor with a good prognosis. Nearly 30 years ago, Lauchlan and Hendrickson et al. recognized a distinct histological type, serous adenocarcinoma (SAC), which has a more aggressive behavior $[1,2]$. SAC is a rare tumor accounting for $4-10 \%$ of all EC $[3,4]$. SAC usually arises from atrophic endometrium and therefore 
occurs in relatively older women $[3,5]$. SAC differs from endometrioid adenocarcinoma (EAC) in a number of respects; estrogen receptor (ER) and progesterone receptor $(\mathrm{PR})$, usually present in normal endometrium and EAC, are less frequently expressed in SAC [6]. The mutation of TP53, coding for the tumor suppressor $\mathrm{p} 53$, is considered to be an early event in SAC as the mutation has been demonstrated in intraepithelial carcinoma [7]. Ki-67, a nuclear protein associated with cell proliferation, is more extensively expressed in SAC compared to EAC [8]. In contrast to EAC, SAC has not been found to be associated with PTEN and KRAS mutation or microsatellite instability [9]. Recent gene expression studies have demonstrated different profiles in SAC compared to EAC grade 1 and 2 [10]. SAC is associated with DNA aneuploidy, and most of the tumors show a DNA index $>1.60$ and a higher $5 \mathrm{c}$ exceeding rate (5c ExR) than EAC [11].

The incidence of recurrence after primary therapy is higher in SAC than EAC [12, 13]. Furthermore, SAC is more often diagnosed at advanced stage compared to EAC [3]. In spite of its rarity, SAC has been shown to be responsible for $39 \%$ of all EC-related deaths [4]. However, in an accumulated multinational series of $8,033 \mathrm{EC}$ patients, SAC was found in 323 cases (4\%) with $80 \%$ overall 5-year survival in stage I patients [3]. This indicates that a substantial number of SAC patients have a good prognosis, but reliable prognostic indicators are lacking. In the present study, we evaluated the prognostic role of clinicopathological parameters, DNA ploidy, and immunohistochemical markers in stage I and II SAC.

\section{Materials and methods}

This is a study of consecutive patients with SAC of the endometrium referred to the Norwegian Radium Hospital from October 1998 to December 2007. Altogether, 215 patients were diagnosed with SAC in the period, out of which 73 stage I and II cases were available for DNA ploidy and histological review in hysterectomy specimen. The specimens were retrieved from the archives of the Department of Pathology. Data regarding FIGO stage (2009), the extent of myometrial invasion, and lymphovascular invasion (LVI) were retrieved from pathological reports. Clinical data were provided by the Department of Gynecologic Oncology. Data on patient death were acquired from the death register of the Central Bureau of Statistics, which is based on the transmitted death certificates by the patient's physician. Simple and radical hysterectomies were performed in 60 and 13 cases, respectively. In 29 patients, infracolic omentectomy was performed. Both pelvic and paraaortic lymphadenectomy were done in 16 cases and only pelvic lymphadenectomy in 26 cases.
Twenty-three patients received adjuvant chemotherapy, ten patients received radiotherapy, and five patients received both. Patients with recurrence were treated with chemotherapy (six cases), radiotherapy (five cases), hormonal therapy (one case), both chemotherapy and radiotherapy (two cases), chemotherapy and antihormonal treatment (one case), and all three therapeutic modalities (two cases). Ethical approval for the study was obtained from the Regional Committee for Medical and Health Research Ethics, Southeastern Norway.

\section{Histologic review}

All H\&E slides from the area from which DNA ploidy and immunohistochemical analysis were performed were independently reviewed by three experienced gynecological pathologists (BD, BR, and VA). The World Health Organization recommendation [14] was used to classify the tumors. Pure SAC and SAC mixed with EAC were entered in the study. Discrepant cases were discussed at a consensus session.

\section{DNA image cytometry}

Using thick $50-\mu \mathrm{m}$ sections from paraffin-embedded blocks from hysterectomy specimens, a monolayer of cells was prepared on a slide. After staining with the Feulgen method, nuclear DNA content was measured indirectly using Ploidy Work Station (Room4, Crowborough, UK). DNA ploidy histograms were created using PWS classifier (Room4, Crowborough, UK). The histograms were classified as diploid, aneuploid (DNA index, DI, 1.06-1.89 and >2.10), tetraploid (DI 1.90-2.10), and polyploid. DNA ploidy-related parameters such as DI, $5 c$ ExR, and 9c exceeding rate (9c ExR) of the tumors were also noted. A detailed description of the procedure, DNA content measurement, and histogram classification criteria are given elsewhere [11].

Immunohistochemistry

From the formalin-fixed, paraffin-embedded tissue blocks of the hysterectomy specimen, $4-5-\mu \mathrm{m}$ thick sections were cut and stained using a Dako Autostainer. Sections were deparaffinized, and epitopes were unmasked using Dako PT link with high $\mathrm{pH}$ buffer for $20 \mathrm{~min}$. Endogenous peroxidase was blocked using EnVision FLEX Peroxidase-Blocking Reagent. The sections were incubated with primary mouse monoclonal antibodies against p53 (1:5,000, Santa Cruz Biotechnology, Inc., Santa Cruz, CA), ER (1:200, Novocastra Laboratories Ltd, Newcastle-upon-Tyne, UK), PR (1:300, Novocastra Laboratories Ltd.), and Ki-67 (1:200, DakoCytomation, Glostrup, Denmark) for 
Table 1 Recurrence rate, progression-free survival, and overall survival based on clinical and pathological parameters in patients with stage I and II serous adenocarcinoma

\begin{tabular}{|c|c|c|c|c|c|c|c|c|c|}
\hline \multirow[t]{2}{*}{ Variables } & \multirow[t]{2}{*}{ Categories } & \multirow{2}{*}{$\begin{array}{l}\text { Number of } \\
\text { patients }(\%)\end{array}$} & \multirow{2}{*}{$\begin{array}{l}\text { Number of } \\
\text { recurrence (\%) }\end{array}$} & \multirow{2}{*}{$\begin{array}{l}\text { Number of } \\
\text { death }(\%)\end{array}$} & \multirow{2}{*}{$\begin{array}{l}\text { 5-year } \\
\text { recurrence } \\
\text { rate } \pm \mathrm{SE} \\
(\%)\end{array}$} & \multicolumn{2}{|l|}{ 5-year PFS } & \multicolumn{2}{|l|}{ 5-year OS } \\
\hline & & & & & & $\begin{array}{l}5 \text {-year PFS } \\
\pm \text { SE }(\%)\end{array}$ & $\begin{array}{l}p \\
\text { value }^{\mathrm{a}}\end{array}$ & $\begin{array}{l}5 \text {-year OS } \\
\pm \text { SE }(\%)\end{array}$ & $\begin{array}{l}p \\
\text { value }^{\mathrm{a}}\end{array}$ \\
\hline Age & $\begin{array}{l}<72 \\
\geq 72\end{array}$ & $\begin{array}{l}28(50) \\
28(50)\end{array}$ & $\begin{array}{l}6(21) \\
8(29)\end{array}$ & $\begin{array}{l}9(32) \\
19(68)\end{array}$ & $\begin{array}{l}26 \pm 10 \\
32 \pm 10\end{array}$ & $\begin{array}{l}59 \pm 11 \\
38 \pm 11\end{array}$ & $<0.01$ & $\begin{array}{l}69 \pm 10 \\
56 \pm 10\end{array}$ & $<0.01$ \\
\hline \multirow[t]{2}{*}{ Stage } & $\begin{array}{l}\text { IA } \\
\text { IB }\end{array}$ & $\begin{array}{l}43(77) \\
8(14)\end{array}$ & $\begin{array}{l}10(23) \\
1(13)\end{array}$ & $\begin{array}{l}19(44) \\
5(63)\end{array}$ & $\begin{array}{l}29 \pm 8 \\
17 \pm 15\end{array}$ & $\begin{array}{l}52 \pm 10 \\
25 \pm 20\end{array}$ & NS & $\begin{array}{l}69 \pm 8 \\
38 \pm 17\end{array}$ & NS \\
\hline & II & $5(9)$ & $3(60)$ & $4(80)$ & $60 \pm 22$ & $40 \pm 22$ & & $40 \pm 22$ & \\
\hline \multirow[t]{2}{*}{$\begin{array}{l}\text { Myometrial } \\
\text { invasion }\end{array}$} & $\begin{array}{l}\text { No invasion } \\
<\text { Half } \\
\text { myometrium }\end{array}$ & $\begin{array}{l}10(18) \\
34(61)\end{array}$ & $\begin{array}{l}2(20) \\
9(26)\end{array}$ & $\begin{array}{l}3(30) \\
17(50)\end{array}$ & $\begin{array}{l}32 \pm 21 \\
30 \pm 9\end{array}$ & $\begin{array}{l}68 \pm 21 \\
45 \pm 11\end{array}$ & NS & $\begin{array}{l}90 \pm 10 \\
60 \pm 9\end{array}$ & NS \\
\hline & $\begin{array}{l}>\text { Half } \\
\text { myometrium }\end{array}$ & $12(21)$ & $3(25)$ & $8(67)$ & $28 \pm 14$ & $38 \pm 15$ & & $42 \pm 14$ & \\
\hline \multirow[t]{3}{*}{$\begin{array}{l}\text { Adjuvant } \\
\text { therapy }\end{array}$} & $\begin{array}{l}\text { Chemotherapy } \\
\text { Radiotherapy }\end{array}$ & $\begin{array}{l}19(34) \\
10(18)\end{array}$ & $\begin{array}{l}6(32) \\
0\end{array}$ & $\begin{array}{l}8(42) \\
3(30)\end{array}$ & $\begin{array}{l}40 \pm 14 \\
-b\end{array}$ & $\begin{array}{l}60 \pm 14 \\
79 \pm 13\end{array}$ & 0.02 & $\begin{array}{l}78 \pm 10 \\
80 \pm 13\end{array}$ & 0.04 \\
\hline & Both & $2(4)$ & 0 & 0 & $-^{\mathrm{b}}$ & $-^{\mathrm{b}}$ & & $-^{\mathrm{b}}$ & \\
\hline & $\begin{array}{l}\text { No adjuvant } \\
\text { therapy }\end{array}$ & $25(45)$ & $8(32)$ & $17(68)$ & $42 \pm 13$ & $22 \pm 10$ & & $42 \pm 10$ & \\
\hline
\end{tabular}

PFS progression-free survival, $O S$ overall survival, $S E$ standard error, $N S$ not significant

${ }^{a}$ Overall $p$ value by log-rank test

${ }^{\mathrm{b}}$ No statistics were computed because all cases were censored

30 min. EnVision FLEX+ Mouse (LINKER) was applied for $15 \mathrm{~min}$ for signal amplification. After applying Dako EnVision FLEX+HRP for $30 \mathrm{~min}$, diluted DAB chromogen was applied for $10 \mathrm{~min}$. The slides were counterstained with hematoxylin and mounted. Relevant positive and negative controls were used with each antibody, with satisfactory results. In mixed tumors, expression was scored only in the serous component. Based on percentage of cells showing immunoexpression, slides were scored as negative $(0-10 \%)$, weakly positive (11-50\%), and strongly positive (51-100\%).

Statistical analysis

Predictive Analytics SoftWare statistics 18 (SPSS Inc., Chicago, IL) was used for statistical analysis. All statistical tests were two-sided, and $p$ value $<0.05$ was considered as statistically significant. Progression-free survival (PFS) was calculated from the hysterectomy date to recurrence or 31 March 2009. Both recurrence and death due to any cause were considered as an event for PFS. Overall survival (OS) was calculated from the date of surgery to death or 31 March 2011 using death due to any cause as an event. For survival analysis, median value was used as cutoff for age, $5 c$ ExR, and 9c ExR. The Kaplan-Meier method was used to calculate the 5-year recurrence rate, PFS, and OS. Log-rank test was used for univariate survival analysis.

\section{Results}

\section{Histological review}

After review and consensus discussion, all three or two of the three pathologists agreed on the SAC diagnosis in 56 cases, which were included in further analyses. We used the reviewed diagnosis as the basis for the present study as it was found to be better in predicting prognosis in EC [15].

\section{Patient characteristics}

The median age of patients with SAC was 73 years (mean, 72; range, 56-89 years). There were 43 patients diagnosed at stage IA, 8 at stage IB, and 5 at stage II (Table 1). There was no myometrial invasion in 10 cases, invasion of less than half the myometrial thickness in 34 cases, and more than half in 12 cases. LVI was present in 17 cases. Recurrence was detected in 14 patients, of whom 2 had recurrence in the vagina, 5 in the pelvis, and 7 outside the pelvis. The majority of recurrences occurred in the first year after operation (eight cases); the earliest detected was after 3 months. 
Table 2 Recurrence rate, progression-free survival, and overall survival based on DNA ploidy and immunohistochemical markers in patients with stage I and II serous adenocarcinoma

\begin{tabular}{|c|c|c|c|c|c|c|c|c|c|}
\hline \multirow[t]{2}{*}{ Variables } & \multirow[t]{2}{*}{ Categories } & \multirow{2}{*}{$\begin{array}{l}\text { Number of } \\
\text { patients }(\%)\end{array}$} & \multirow{2}{*}{$\begin{array}{l}\text { Number of } \\
\text { recurrences }(\%)\end{array}$} & \multirow{2}{*}{$\begin{array}{l}\text { Number of } \\
\text { death }(\%)\end{array}$} & \multirow{2}{*}{$\begin{array}{l}\text { 5-year recurrence } \\
\text { rate } \pm \text { SE }(\%)\end{array}$} & \multicolumn{2}{|l|}{ 5-year PFS } & \multicolumn{2}{|l|}{ 5-year OS } \\
\hline & & & & & & $\begin{array}{l}5 \text {-year PFS } \\
\pm \text { SE (\%) }\end{array}$ & $\begin{array}{l}p \\
\text { value }^{\mathrm{a}}\end{array}$ & $\begin{array}{l}\text { 5-year OS } \\
\pm \text { SE }(\%)\end{array}$ & $\begin{array}{l}p \\
\text { value }^{\mathrm{a}}\end{array}$ \\
\hline \multirow[t]{2}{*}{$\begin{array}{l}\text { DNA } \\
\text { ploidy }\end{array}$} & $\begin{array}{l}\text { Diploid } \\
\text { Aneuploid }\end{array}$ & $\begin{array}{l}19(34) \\
29(52)\end{array}$ & $\begin{array}{l}2(11) \\
8(28)\end{array}$ & $\begin{array}{l}7(37) \\
15(52)\end{array}$ & $\begin{array}{l}10 \pm 7 \\
38 \pm 13\end{array}$ & $\begin{array}{l}61 \pm 13 \\
43 \pm 12\end{array}$ & \multirow[t]{2}{*}{ NS } & $\begin{array}{l}71 \pm 11 \\
64 \pm 9\end{array}$ & \multirow[t]{2}{*}{ NS } \\
\hline & Tetraploid & $8(14)$ & $4(50)$ & $6(75)$ & $53 \pm 19$ & $38 \pm 17$ & & $38 \pm 17$ & \\
\hline $5 \mathrm{c} \operatorname{ExR}^{\mathrm{b}}$ & $\begin{array}{l}<2.28 \% \\
\geq 2.28 \%\end{array}$ & $\begin{array}{l}28(50) \\
28(50)\end{array}$ & $\begin{array}{l}4(14) \\
10(36)\end{array}$ & $\begin{array}{l}10(36) \\
18(64)\end{array}$ & $\begin{array}{l}15 \pm 7 \\
48 \pm 13\end{array}$ & $\begin{array}{l}58 \pm 11 \\
39 \pm 11\end{array}$ & $<0.01$ & $\begin{array}{l}66 \pm 9 \\
59 \pm 10\end{array}$ & 0.02 \\
\hline $9 \mathrm{c} \mathrm{ExR}^{\mathrm{b}}$ & $\begin{array}{l}<0.07 \% \\
\geq 0.07 \%\end{array}$ & $\begin{array}{l}27(48) \\
29(52)\end{array}$ & $\begin{array}{l}5(19) \\
9(31)\end{array}$ & $\begin{array}{l}12(44) \\
16(55)\end{array}$ & $\begin{array}{l}28 \pm 10 \\
33 \pm 11\end{array}$ & $\begin{array}{l}51 \pm 11 \\
45 \pm 12\end{array}$ & NS & $\begin{array}{l}65 \pm 9 \\
59 \pm 10\end{array}$ & NS \\
\hline \multirow[t]{2}{*}{ P53 } & $\begin{array}{c}\text { Negative } \\
(\leq 10 \%) \\
\text { Weak }(11- \\
50 \%)\end{array}$ & $11(21)$ & $3(27)$ & $6(55)$ & $73 \pm 13$ & $75 \pm 15$ & \multirow[t]{2}{*}{ NS } & $75 \pm 15$ & \multirow[t]{2}{*}{ NS } \\
\hline & $\begin{array}{l}\text { Strong } \\
(51- \\
100 \%)\end{array}$ & 34 (64) & $11(32)$ & $20(59)$ & $59 \pm 11$ & $34 \pm 10$ & & $49 \pm 9$ & \\
\hline \multirow[t]{3}{*}{ ER } & $\begin{array}{l}\text { Negative } \\
(\leq 10 \%)\end{array}$ & $33(63)$ & $9(27)$ & $17(52)$ & $67 \pm 10$ & $40 \pm 10$ & \multirow[t]{3}{*}{ NS } & $54 \pm 9$ & \multirow[t]{3}{*}{ NS } \\
\hline & $\begin{array}{l}\text { Weak }(11- \\
50 \%)\end{array}$ & $13(25)$ & $4(31)$ & $9(69)$ & $67 \pm 14$ & $54 \pm 14$ & & $69 \pm 13$ & \\
\hline & $\begin{array}{l}\text { Strong } \\
(51- \\
100 \%)\end{array}$ & $6(12)$ & $1(17)$ & $1(17)$ & $83 \pm 15$ & $83 \pm 15$ & & $83 \pm 15$ & \\
\hline \multirow[t]{3}{*}{ PR } & $\begin{array}{l}\text { Negative } \\
(\leq 10 \%)\end{array}$ & $38(73)$ & 7 (18) & $20(53)$ & $80 \pm 7$ & $50 \pm 10$ & \multirow[t]{3}{*}{ NS } & $58 \pm 8$ & \multirow[t]{3}{*}{ NS } \\
\hline & $\begin{array}{l}\text { Weak (11- } \\
50 \%)\end{array}$ & $12(23)$ & $6(50)$ & $7(58)$ & $35 \pm 18$ & $31 \pm 16$ & & $58 \pm 14$ & \\
\hline & $\begin{array}{l}\text { Strong } \\
(51- \\
100 \%)\end{array}$ & $2(4)$ & 0 & 0 & $-^{\mathrm{c}}$ & $-{ }^{c}$ & & $-^{\mathrm{c}}$ & \\
\hline \multirow[t]{3}{*}{ Ki-67 } & $\begin{array}{l}\text { Negative } \\
(\leq 10 \%)\end{array}$ & $1(2)$ & 0 & $1(100)$ & $-{ }^{c}$ & $-^{\mathrm{c}}$ & \multirow[t]{3}{*}{ NS } & $-^{\mathrm{c}}$ & \multirow[t]{3}{*}{ NS } \\
\hline & $\begin{array}{l}\text { Weak (11- } \\
50 \%)\end{array}$ & $21(46)$ & $9(43)$ & $16(76)$ & $51 \pm 12$ & $27 \pm 11$ & & $47 \pm 11$ & \\
\hline & $\begin{array}{l}\text { Strong } \\
\quad(51- \\
100 \%)\end{array}$ & $24(52)$ & $2(8)$ & $8(33)$ & $90 \pm 7$ & $74 \pm 9$ & & $75 \pm 9$ & \\
\hline
\end{tabular}

$P F S$ progression-free survival, $O S$ overall survival, $S E$ standard error, $5 c E x R$ 5c exceeding rate, $9 c$ ExR 9c exceeding rate, $E R$ estrogen receptor, $P R$ progesterone receptor, $N S$ not significant

${ }^{\text {a }}$ Overall $p$ value by log-rank test

${ }^{\mathrm{b}}$ Median cutoff was used to group the cases

${ }^{\mathrm{c}}$ No statistics were computed because all cases were censored

\section{DNA ploidy}

The mean and median CVs of the diploid peaks were 3.02 and 2.80 , respectively. The mean number of nuclei analyzed was 1,005 (median, 1,192; range, 280-2,546). The majority of tumors $(n=29,52 \%)$ were aneuploid, of which 2 cases had $\mathrm{DI} \leq 1.20$ and 27 cases had DI> 1.20. Tetraploidy and diploidy were detected in $8(14 \%)$ and $19(34 \%)$ tumors, respectively (Table 2).
Median 5c ExR was 2.28 (mean, $6.08 \%$; range, 0$72.82 \%$ ). Median 9c ExR was 0.07 (mean, $0.42 \%$; range, $0-13.76 \%)$.

Immunohistochemistry

Immunohistochemistry was performed in 53 cases for $\mathrm{p} 53,52$ cases for ER and PR, and 46 cases for Ki-67. The majority of tumors $(n=34,64 \%)$ had strong nuclear expression of 
a

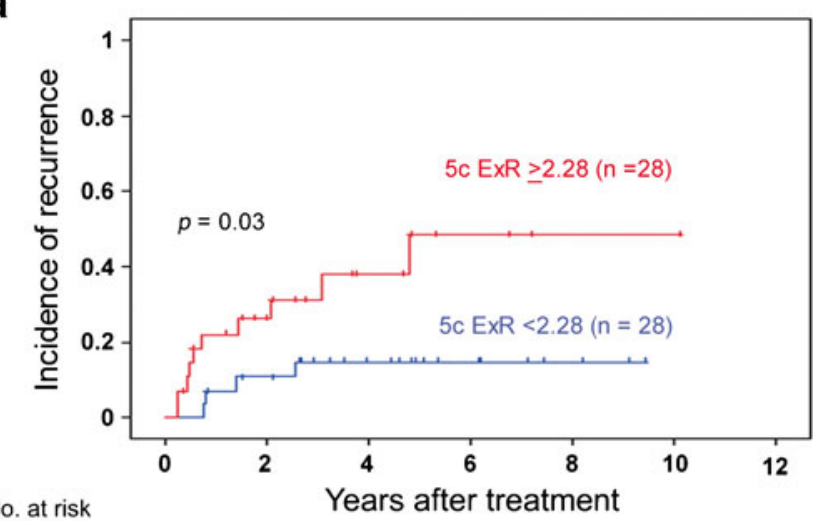

No. at risk

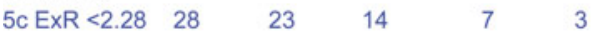

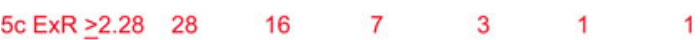

b

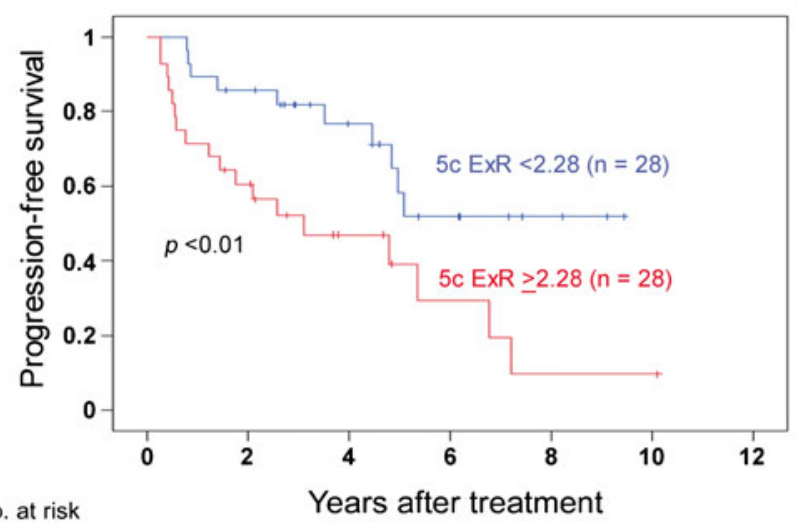

No. at risk

$5 c$ ExR $<2.28 \quad 28$

5 c ExR $\geq 2.28 \quad 28$

C

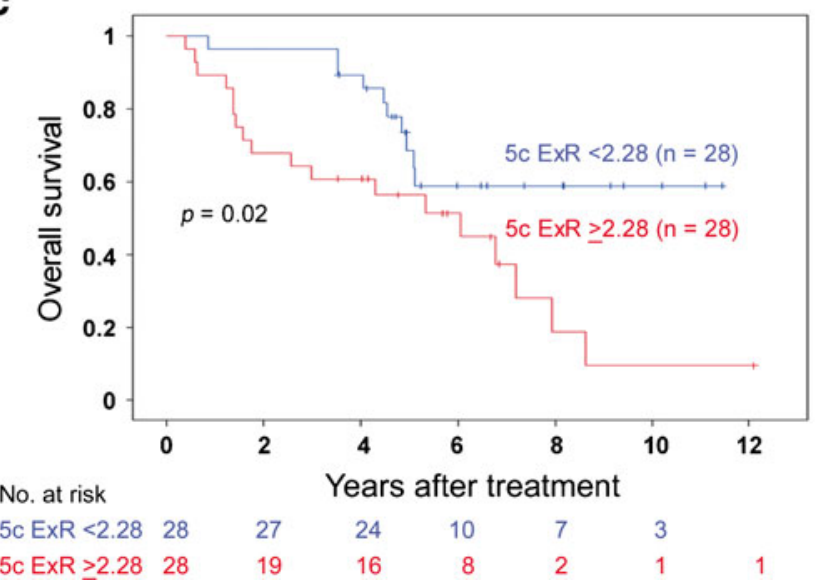

Fig. 1 Recurrence rate, progression-free survival, and overall survival based on $5 \mathrm{c}$ exceeding rate in patients with serous adenocarcinoma stage I and II

p53 in $>50 \%$ of cells. ER and PR expression in $>50 \%$ of cells was found in six (12\%) and two (4\%) tumors, respectively. Ki-67 score $>50 \%$ was seen in $24(52 \%$ ) cases (Table 2 ).
Survival analysis

Altogether, 14 patients had recurrent disease, and 28 patients died during the follow-up period. The 5-year PFS and OS for all cases were $48 \pm 9$ and $62 \pm 7 \%$, respectively. Patients with aneuploid and tetraploid tumors had a higher recurrence rate and lower 5-year PFS and OS compared to patients with diploid tumors (Table 2). DNA ploidy approached, but did not reach statistical significance for recurrence $(p=0.09)$. A DNA ploidy parameter, $5 \mathrm{c}$ ExR, was found to be prognostic for 5-year recurrence rate $(p=0.03)$, PFS $(p<0.01)$, and OS ( $p=0.02$; Table 2, Fig. 1). p53, ER, PR, and Ki67 expression was unrelated to prognosis. Stage, the extent of myometrial invasion, LVI, lymphadenectomy, and the extent of hysterectomy failed to show prognostic significance (Table 1). Shorter 5-year PFS (22\%) and OS (42\%) were observed for patients who did not receive any form of adjuvant therapy. Notably, patients who received radiotherapy as adjuvant treatment had no recurrences.

\section{Discussion}

In this study, we evaluated the prognostic importance of various clinical, pathological, DNA ploidy, and immunohistochemical markers in early-stage SAC. The only significant prognostic marker we found was the $5 \mathrm{c}$ ExR, a parameter that can simply be extracted from a DNA ploidy analysis. The explanation is that $5 \mathrm{c}$ ExR is high in proliferating tetraploid tumors and aneuploid tumors with high DI. Non-diploid tumors with low S-phase fraction and diploid tumors show low 5c ExR. Therefore, less aggressive nondiploid tumors are separated from highly aggressive tumors. Earlier, Strang et al. reported that $5 \mathrm{c}$ ExR is a prognostic parameter in patients with EC [16]. In our previous study, in which exclusively endometrioid carcinoma was analyzed, $5 \mathrm{c}$ ExR ( $1 \%$ as a cutoff) failed to show prognostic importance [13]; however, when the cutoff was changed to 2.28, same as in this series, 5c ExR was a prognostic indicator (unpublished data). Therefore, 5c ExR can be an objective DNA ploidy parameter for patients with endometrial carcinoma. Additionally, 5c ExR has also been found to be a prognostic parameter in other cancers, e.g., non-small cell lung carcinoma, uterine cervical carcinoma, neuroendocrine tumors, and ependymoma [17-20]. There was also a tendency, though not statistically significant, for patients with diploid tumors to have lower recurrence rate and increased overall survival. Kato et al. investigated 30 patients with $\mathrm{SAC}$ in all stages and found no association between aneuploidy and survival [21].

SAC is usually diagnosed based on morphology alone. However, some tumors are difficult to classify due to overlapping features between SAC and EAC [22-24]. We 

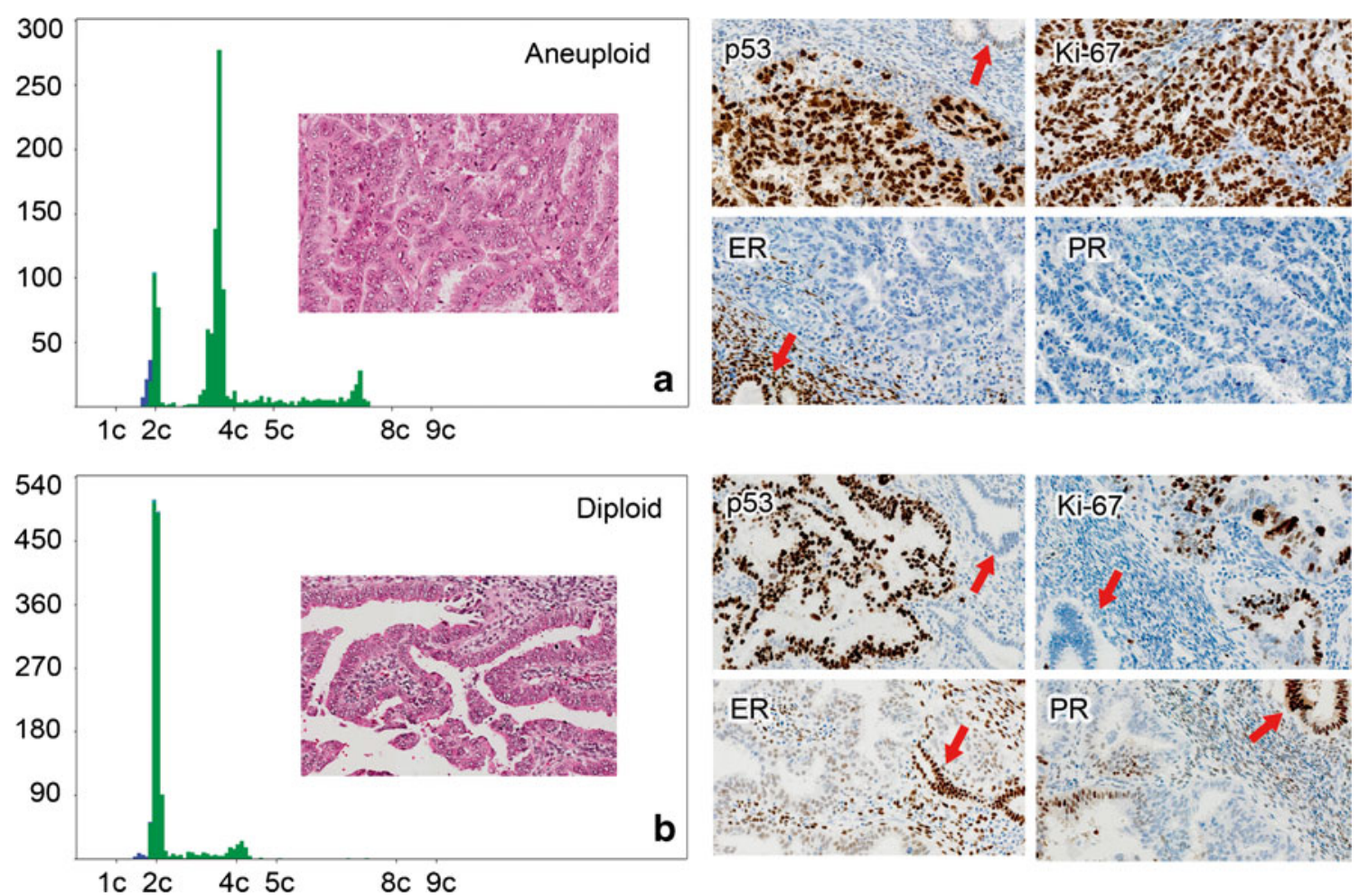

Fig. 2 a DNA ploidy histogram of an aneuploid serous adenocarcinoma showing high 5c ExR, strongly positive p53, and Ki-67 expression and negative staining for estrogen and progesterone receptors. b A

observed lack of agreement in a substantial number of cases at consensus session. This indicates that SAC, even after being a distinct entity for more than 30 years, is not so easy to diagnose morphologically in a certain number of cases. Nordström et al. reported that $12 \%$ of EC were reclassified as SAC following histological review of 266 cases [25]. The differential diagnosis of SAC included both benign and malignant lesions, including EAC with small non-villous papillae, papillary $\mathrm{CAC}$, and malignant mullerian mixed tumors [26]. Therefore, there is a need for ancillary techniques for SAC diagnosis. Many pathologists use overexpression of p53 and Ki-67 together with underexpression of ER and PR as additional diagnostic aids (Fig. 2). Since SAC is associated with aneuploidy with DI $>1.60$, DNA ploidy might also be a potential parameter supporting the diagnosis [11]. There are reports on markers such as insulin-like growth factor II mRNA-binding protein 3 which may be useful in this differential diagnosis [27].

In EC, stage, myometrial invasion, and LVI are established prognostic parameters [28]. However, these parameters had no prognostic role in our series. Grade and depth of myometrial invasion did not predict prognosis in SAC in an earlier study, and these tumors are currently not graded [21]. Goff et al. analyzed 50 cases of SAC and similarly found no prognostic importance for the depth of myometrial invasion [29].

diploid serous adenocarcinoma with low 5c ExR showing strong expression of p53 and $\mathrm{Ki}-67$ and weak expression of estrogen and progesterone receptors. Benign glands are marked with red arrows

p53 mutation is considered to be an early event in SAC since it is found in serous intraepithelial carcinoma [7]. Usually, mutation leads to overexpression of mutant p53 protein which can be detected using immunohistochemistry. However, nonsense mutation leads to total absence of protein expression [30]. Although overexpression of p53 has been reported to be a prognostic factor in EC [31], p53 immunostaining was not informative of disease outcome in the present series of SAC. This finding is similar to the observation by Alkushi et al. where p53 overexpression was not a prognostic indicator in patients with SAC but was of prognostic importance in the analysis of patients with low-grade EAC [32]. p53 expression may be helpful in morphologically ambiguous cases due to the higher rate of overexpression in SAC [22]. ER and PR are expressed in normal endometrial tissue, as well as in the majority of EAC, mainly of low grade. In SAC, ER and PR expression was found to be lower than in EAC [33]. ER and PR expression was unrelated to prognosis in our series. High expression of $\mathrm{Ki}-67$, a proliferation marker, was shown to be associated with poor prognosis in patients with EC [31]. However, Ki-67 had no prognostic value in our series of SAC.

In conclusion, established clinicopathological parameters and immunohistochemical markers do not provide prognostic information for patients in SAC stage I and II with high risk of 
recurrence and death of disease. A DNA ploidy parameter, $5 \mathrm{c}$ exceeding rate, may be a prognostic marker in this patient group and should be further validated in larger series.

Acknowledgments The authors thank Erika Thorbjørnsen, Signe Eastgate, Jeanne D' Arc Karerwa, and Ellen Hellesylt for their technical assistance in DNA ploidy analysis and immunohistochemistry. Special thanks to Odd Røyne and Yunyong Wang for database management and clinical data entry, respectively. This work was supported by Radium Hospital Foundation.

Conflict of interest The authors declare no conflict of interest.

Open Access This article is distributed under the terms of the Creative Commons Attribution License which permits any use, distribution, and reproduction in any medium, provided the original author(s) and the source are credited.

\section{References}

1. Hendrickson M, Ross J, Eifel P, Martinez A, Kempson R (1982) Uterine papillary serous carcinoma: a highly malignant form of endometrial adenocarcinoma. Am J Surg Pathol 6:93-108

2. Lauchlan SC (1981) Tubal (serous) carcinoma of the endometrium. Arch Pathol Lab Med 105:615-618

3. Creasman WT, Odicino F, Maisonneuve P, Quinn MA, Beller U, Benedet JL, Heintz AP, Ngan HY, Pecorelli S (2006) Carcinoma of the corpus uteri. FIGO 26th Annual Report on the Results of Treatment in Gynecological Cancer. Int J Gynaecol Obstet 95 (Suppl 1):S105-S143

4. Hamilton CA, Kapp DS, Chan JK (2008) Clinical aspects of uterine papillary serous carcinoma. Curr Opin Obstet Gynecol 20:26-33

5. Abeler VM, Kjørstad KE (1990) Serous papillary carcinoma of the endometrium: a histopathological study of 22 cases. Gynecol Oncol 39:266-271

6. Halperin R, Zehavi S, Habler L, Hadas E, Bukovsky I, Schneider D (2001) Comparative immunohistochemical study of endometrioid and serous papillary carcinoma of endometrium. Eur $\mathrm{J}$ Gynaecol Oncol 22:122-126

7. Sherman ME, Bur ME, Kurman RJ (1995) p53 in endometrial cancer and its putative precursors: evidence for diverse pathways of tumorigenesis. Hum Pathol 26:1268-1274

8. Kallakury BV, Ambros RA, Hayner-Buchan AM, Sheehan CE, Malfetano JH, Ross JS (1998) Cell proliferation-associated proteins in endometrial carcinomas, including papillary serous and endometrioid subtypes. Int J Gynecol Pathol 17:320-326

9. Lax SF (2004) Molecular genetic pathways in various types of endometrial carcinoma: from a phenotypical to a molecular-based classification. Virchows Arch 444:213-223

10. Chen Y, Yao Y, Zhang L, Li X, Wang Y, Zhao L, Wang J, Wang G, Shen D, Wei L, Zhao J (2011) cDNA microarray analysis and immunohistochemistry reveal a distinct molecular phenotype in serous endometrial cancer compared to endometrioid endometrial cancer. Exp Mol Pathol 91:373-384

11. Pradhan M, Abeler VM, Danielsen HE, Tropé CG, Risberg BÅ (2006) Image cytometry DNA ploidy correlates with histological subtypes in endometrial carcinomas. Mod Pathol 19:1227-1235

12. Sood BM, Jones J, Gupta S, Khabele D, Guha C, Runowicz C, Goldberg G, Fields A, Anderson P, Vikram B (2003) Patterns of failure after the multimodality treatment of uterine papillary serous carcinoma. Int J Radiat Oncol Biol Phys 57:208-216
13. Pradhan M, Abeler VM, Danielsen HE, Sandstad B, Tropé CG, Kristensen GB, Risberg BÅ (2012) Prognostic importance of DNA ploidy and DNA index in stage I and II endometrioid adenocarcinoma of the endometrium. Ann Oncol 23:1178-84

14. Silverberg SG, Kurman RJ, Nogales F, Mutter GL, Kubik-Huch RA, Tavassoli FA (2003) Tumours of uterine corpus. In: Tavassoli FA, Devilee P (eds) World Health Organization Classification of Tumours: Pathology and Genetics. Tumours of the breast and female genital organs. IARC Press, Lyon, pp 218-232

15. Baak JP, Snijders W, van Diermen B, van Diest PJ, Diepenhorst FW, Benraadt J (2003) Prospective multicenter validation confirms the prognostic superiority of the endometrial carcinoma prognostic index in international Federation of gynecology and obstetrics stage 1 and 2 endometrial carcinoma. J Clin Oncol 21:4214-4221

16. Strang P, Stenkvist B, Bergström R, Stendahl U, Valdes C, Tribukait B (1991) Flow cytometry and interactive image cytometry in endometrial carcinoma. A comparative and prognostic study. Anticancer Res 11:783-788

17. Grote HJ, Friedrichs N, Pomjanski N, Guhde HF, Reich O, Böcking A (2001) Prognostic significance of DNA cytometry in carcinoma of the uterine cervix FIGO stage IB and II. Anal Cell Pathol 23:97-105

18. Maounis NF, Chorti M, Apostolakis E, Ellina E, Blana A, Aggelidou M, Dritsas I, Markidou S (2006) Prognostic impact of deoxyribonucleic acid (DNA) image analysis cytometry and immunohistochemical expression of Ki67 in surgically resected non-small cell lung cancers. Cancer Detect Prev 30:507-514

19. Onguru O, Ulutin C, Celasun B, Gunhan O (2003) DNA ploidy and nuclear morphometry in adult intracranial ependymomas. Clin Neuropathol 22:266-272

20. Raatz H, Böcking A, Hauptmann S (2004) Prognostic impact of DNA-image-cytometry in neuroendocrine (carcinoid) tumours. Cell Oncol 26:81-88

21. Kato DT, Ferry JA, Goodman A, Sullinger J, Scully RE, Goff BA, Fuller AF Jr, Rice LW (1995) Uterine papillary serous carcinoma (UPSC): a clinicopathologic study of 30 cases. Gynecol Oncol 59:384-389

22. Garg K, Leitao MM Jr, Wynveen CA, Sica GL, Shia J, Shi W, Soslow RA (2010) p53 overexpression in morphologically ambiguous endometrial carcinomas correlates with adverse clinical outcomes. Mod Pathol 23:80-92

23. Faratian D, Stillie A, Busby-Earle RM, Cowie VJ, Monaghan $\mathrm{H}$ (2006) A review of the pathology and management of uterine papillary serous carcinoma and correlation with outcome. Int $\mathrm{J}$ Gynecol Cancer 16:972-978

24. Murray SK, Young RH, Scully RE (2000) Uterine endometrioid carcinoma with small nonvillous papillae: an analysis of 26 cases of a favorable-prognosis tumor to be distinguished from serous carcinoma. Int J Surg Pathol 8:279-289

25. Nordström B, Strang P, Lindgren A, Bergström R, Tribukait B (1996) Carcinoma of the endometrium: do the nuclear grade and DNA ploidy provide more prognostic information than do the FIGO and WHO classifications? Int J Gynecol Pathol 15:191-201

26. Clement PB, Young RH (2004) Non-endometrioid carcinomas of the uterine corpus: a review of their pathology with emphasis on recent advances and problematic aspects. Adv Anat Pathol 11:117142

27. Zheng W, Yi X, Fadare O, Liang SX, Martel M, Schwartz PE, Jiang Z (2008) The oncofetal protein IMP3: a novel biomarker for endometrial serous carcinoma. Am J Surg Pathol 32:304-315

28. Abeler VM, Kjørstad KE (1991) Endometrial adenocarcinoma in Norway. A study of a total population. Cancer 67:3093-3103

29. Goff BA, Kato D, Schmidt RA, Ek M, Ferry JA, Muntz HG, Cain JM, Tamimi HK, Figge DC, Greer BE (1994) Uterine papillary serous carcinoma: patterns of metastatic spread. Gynecol Oncol 54:264-268 
30. Mineta H, Borg A, Dictor M, Wahlberg P, Akervall J, Wennerberg J (1998) p53 mutation, but not p53 overexpression, correlates with survival in head and neck squamous cell carcinoma. Br J Cancer 78:1084-1090

31. Salvesen HB, Iversen OE, Akslen LA (1999) Prognostic significance of angiogenesis and $\mathrm{Ki}-67, \mathrm{p} 53$, and p21 expression: a population-based endometrial carcinoma study. J Clin Oncol 17:1382-1390
32. Alkushi A, Lim P, quino-Parsons C, Gilks CB (2002) Markers of proliferative activity are predictors of patient outcome for lowgrade endometrioid adenocarcinoma but not papillary serous carcinoma of endometrium. Mod Pathol 15:365-371

33. Alkushi A, Kobel M, Kalloger SE, Gilks CB (2010) High-grade endometrial carcinoma: serous and grade 3 endometrioid carcinomas have different immunophenotypes and outcomes. Int J Gynecol Pathol 29:343-350 